\title{
Erratum: From three congregations to one autonomous church: The Swaziland Reformed Church
}

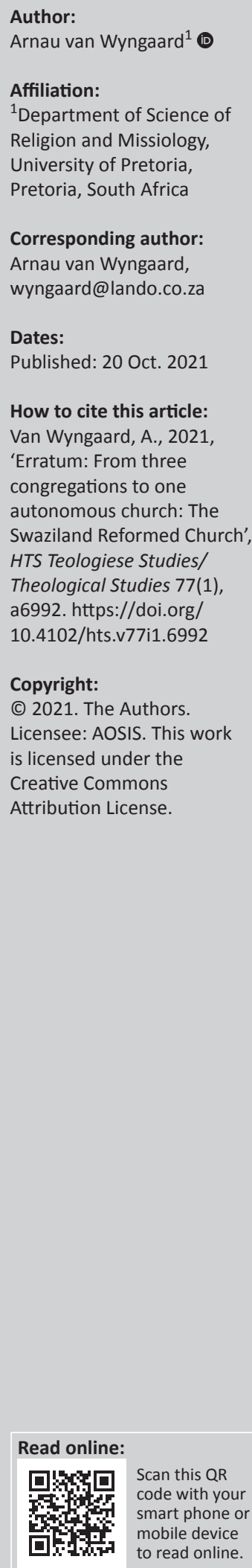

In the version of the article initially published, Van Wyngaard, A., 2018, 'From three congregations to one autonomous church: The Swaziland Reformed Church', HTS Teologiese Studies/Theological Studies 74(1), 4922. https: / / doi.org/10.4102/hts.v74i1.4922, the word moderature was misspelled. The correct spelling of the word should be moderature instead of modarature throughout the article.

This correction does not alter the study's findings of significance or overall interpretation of the study's results. The publisher apologises for any inconvenience caused. 


\section{From three congregations to one autonomous church: The Swaziland Reformed Church}

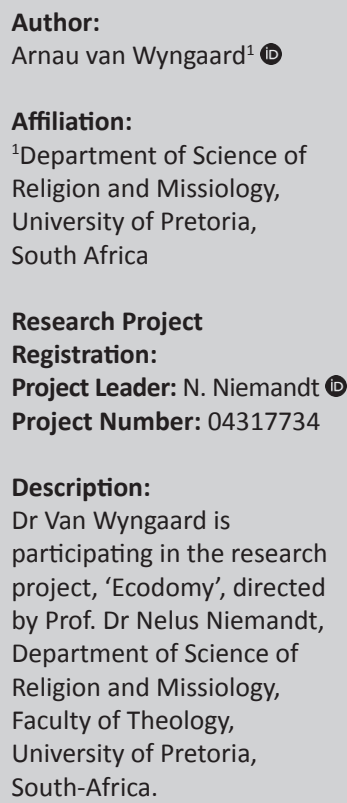

Corresponding author: Arnau van Wyngaard, wyngaard@lando.co.za

Dates:

Received: 29 Jan. 2018

Accepted: 07 Apr. 2018

Published: 24 May 2018

How to cite this article: Van Wyngaard, A., 2018 , 'From three congregations to one autonomous church: The Swaziland Reformed Church', HTS Teologiese Studies/ Theological Studies 74(1), 4922. https://doi.org/ 10.4102/hts.v74i1.4922

\section{Copyright:}

c) 2018. The Authors. Licensee: AOSIS. This work is licensed under the Creative Commons Attribution License.

Read online:

Scan this QR
code with your
smart phone or
mobile device
to read online.

This article covers the time from 1985 to 1992 in the history of the Swaziland Reformed Church (SRC). In 1985, for the first time in its existence, the SRC had four missionaries working in the four districts of the country. At this stage the SRC formed a presbytery within the synodical region of the Dutch Reformed Church in Africa (DRCA) of Northern Transvaal. In 1989 - at its own request - this church became a regional synod within the DRCA. However, not long thereafter, in 1992, it was forced to become an independent Reformed church, even though it still remained part of the family of Dutch Reformed churches. Making use of original documents, this article records this history of the SRC.

\section{Background and methodology}

The history of the Swaziland Reformed Church (SRC) has never been documented before. This is one of the smallest Reformed churches in the world, with approximately 1500 members (SRC Synod 2017). The question can surely be asked why a church, smaller than many Reformed congregations in other countries, would have its own synod. Using a secondary data analysis approach, the present research documents the events that eventually led to the forming of the independent SRC in 1992. The article makes use of original documents, including the official minutes of church meetings as well as official correspondence between different church bodies, all of which have never been accessed before in an academic publication. This historical analysis will be essential background for anyone wishing to do further research on the SRC.

\section{Introduction}

In a previous article, Van Wyngaard (2018:1-7) described the history of the Christian church in Swaziland, including how the SRC was formed and how, by 1985, four missionaries from the Dutch Reformed Church (DRC) in South Africa were working in the three congregations of the SRC. The SRC formed a presbytery within the synodical region of the Dutch Reformed Church in Africa $^{1}$ (DRCA) of Northern Transvaal, ${ }^{2}$ but it soon became clear that a new structure had to be found to enable the Reformed Church in Swaziland to grow. For the leaders of the church at the time, the answer lay in the forming of a synod in Swaziland rather than continuing as a presbytery of the DRCA.

\section{The presbytery of Swaziland ${ }^{3}$}

At a meeting of the Swazilandse Sendingkommissie (SwSK) held in 1976, it was reported that the black congregations in Swaziland would henceforth form part of the presbytery of Piet Retief (SwSK 1976:1). According to Article 29 of the church order of the DRC, '[ $n$ ]eighbouring congregations are grouped together in presbyteries as an expression of the church's interrelation and with a view to proper church discipline' (DRC 2011:5). Furthermore, the task of the presbytery, according to Article 31 of the church order (DRC 2011:6), includes the following: church visitation; the supervision of the congregations; to see to it that church councils and congregations fulfil their vocation; advice and help to church councils; the establishment of new congregations or dissolution of congregations at the request of church councils and the determination of congregation boundaries; attending to matters that are presented to the presbytery meeting either 1.In 1985, four churches within the "family of Dutch Reformed Churches coexisted in South Africa, sharing the same doctrine and
confessions of faith but only distinguished on the grounds of ethnicity: (1) white people: Dutch Reformed Church (Nederduitse
Gereformeerde Kerk). (2) mixed race: Dutch Reformed Mission Church (NG Sendingkerk). (3) Indian community: Reformed Church in
Africa. (4) black people: Dutch Reformed Church in Africa (NG Kerk in Afrika).

2.Northern-Transvaal coincides more or less with the present Limpopo Province in South Africa.

3.The Reformed churches use a 'presbyterian' system where the church is governed on the congregational level by the ministers, elders and deacons. Although reference is made to 'major' and 'minor' church assemblies, this does not imply that one assembly is above another but rather that they have different objectives. In the DRCA, congregations in a certain geographical area are grouped together in a presbytery, a number of presbyteries form a regional synod and all the regional synods form the general synod. 
in the first instance or by way of appeal; the supervision and discipline of all elders, deacons and ministers of the Word, which include retired ministers of the Word and ministry candidates; and the appointment of substitute ministers of the Word.

Annual presbytery meetings are held primarily with a view to discuss reports on the work being done in the different congregations. As early as 1980, the Swaziland delegation to the presbytery of Piet Retief requested that the congregations in Swaziland be allowed to form their own presbytery, while the remaining congregations within the presbytery continue as the presbytery of Piet Retief (RVPR 1980:7). ${ }^{4}$ According to Article 29 of the church order (DRC 2011) it is the task of the synod to decide about the grouping of congregations within presbyteries. This request from the Swaziland congregations was therefore forwarded to and approved by the DRCA synod of Northern Transvaal at its assembly in 1984 (BR 1984:46). ${ }^{5}$ A request was also made that the churches in Swaziland use a more indigenous name (BR 1983:1), which was approved in principal by the presbytery of Piet Retief (BR 1983:4).

The synod of the DRCA of Northern Transvaal (DRCA NTvl) met during June 1984. Immediately after the synod had approved the forming of the presbytery of Swaziland and while still in Mamelodi, where the synod meeting had taken place, the delegates from Swaziland constituted as a new presbytery on 25 June 1984. Rev. H.L. Pretorius was elected as chairperson and Rev. J.M. Louw as secretary (RVS 1984a). ${ }^{6}$ From the start it was clear that the newly formed presbytery of Swaziland was taking up its task with vigour and a sense of earnestness. At its very first meeting, discussions on the boundaries of the congregations, with special regard to the forming of a fourth congregation, was on the agenda.

At its second meeting on 23 November 1984, Rev. Louw gave notice to the presbytery that he intended to table a suggestion at the following meeting, in accordance with the earlier proposal approved by the presbytery of Piet Retief as well as the SwSK, that the name of the church in Swaziland be changed to the 'Swaziland Reformed Church' (RK 1984:2;7 RVS 1984b:3; SwSK 1984:3). On 30 January 1985 this name was adopted by the Swaziland presbytery (RVS 1985a:2).

The main reason why this name change had become important was because of the legacy of the DRC in South Africa, which for many years had been an avid supporter of the apartheid policy of the then-ruling National Party. In Swaziland the DRC was often referred to as the 'apartheid

4.The abbreviation RVPR refers to the presbytery of Piet Retief as it is known in the Afrikaans language, which is Ring van Piet Retief.

5.Synods and presbyteries often publish a list of decisions taken during a genera meeting. In Afrikaans this is known as a Bes/uiteregister and for the purpose of this article abbreviated to $B R$.

6.RVS refers to the newly formed presbytery of Swaziland, or Ring van Swaziland, as these minutes were, at that time, still recorded in Afrikaans, the official language of the DRCA.

7.The executive committee of a presbytery is known in Afrikaans as a Ringskommissie and abbreviated as RK. church' or 'iDutch', and in an attempt to distance themselves from the racist policy of South Africa it was believed that a more indigenous name for the church in Swaziland had become essential. However, this decision did not mean that the church in Swaziland had broken its bond with the DRCA, as it was still part of the DRCA NTvl and still fell under the governance of the DRCA synod. To illustrate this point, at its first general meeting, the heading of the minutes of the meeting of the presbytery of Swaziland reads: N.G.K.A. Noord Transvaal. Ring Van Swaziland. Swaziland Reformed Church [DRCA Northern Transvaal. Presbytery of Swaziland. Swaziland Reformed Church] (RVS 1985b:1).

During this meeting on 21 September 1985, a decision was made that annual training and refresher courses for church workers would be organised. The first of these courses was planned for January 1986 (RVS 1985b:4) and Prof. F.S. Malan, then professor in New Testament at the Turfloop Theological School, based at Sovenga about $30 \mathrm{~km}$ north of Polokwane, was invited to facilitate this training course.

\section{The synod of Swaziland}

At its third general meeting in September 1987, Rev. W.C. Bester, secretary of the presbytery, expressed concern about the name of the SRC in his report to the synod. His concern was that it might seem as if the SRC was no longer part of the DRCA NTvl and his feeling was that the name should be taken into reconsideration (RVS 1987:1). After a discussion about the name of the church, the following decision was approved. The Presbytery decides that the Commission of the Presbytery will inquire into:

1. the possibility to form our own synod in Swaziland;

2. problems which may be encountered if we do form our own synod, and

3. once the investigation is finished, to call up a meeting of the Presbytery, so that a suggestion may be made to the coming meeting of the Synod in 1988. (RVS 1987:2)

To rule out any misunderstanding, the meeting emphasised that the presbytery of Swaziland was still part of the synod of Northern Transvaal (RVS 1987:2). It was decided that Dr J.J. (Dons) Kritzinger, then director of the Institute for Missiological Research (ISWEN) situated at the University of Pretoria, would be asked to lead the 1988 church workers' conference. He eagerly accepted the invitation to be in Swaziland from 15 to 20 February $1988 .{ }^{8}$ As all the presbytery members had to be present at the conference, they were requested to attend a special meeting of the presbytery on the last day of the conference 'to decide on the future of the work of our church in Swaziland with special reference to a new structure of the ministry in our church'. ${ }^{9}$

What is evident is that a feeling of discontent existed among the church leaders regarding the church structures that were

8.Letter from Dr J.J. Kritzinger to the secretary of the presbytery of Swaziland, dated 12 October 1987.

9.Letter from the secretary of the presbytery of Swaziland, written mid-January 1988. 
being maintained in Swaziland and that an answer needed to be found for the way forward. The church workers' conference, led by Dr Kritzinger, became the catalyst for change. Frustrations were aired throughout the conference. One of the accusations directed towards the DRCA structure was that the church was being governed by the church order rather than by the Word of God. Towards the end of the conference, some people felt that the church in Swaziland had to break radically with the DRCA and become independent. Others felt that it would be better to maintain the status quo and continue as presbytery under the DRCA NTvl. Rev. H.E. Basson then suggested a third possibility, namely to become a regional synod of the DRCA, in practice meaning that the church in Swaziland would no longer be part of the regional synod of Northern Transvaal but would become the regional synod of Swaziland while still maintaining its bond with the larger DRCA.

His suggestion served before the special meeting of the presbytery on 19 February 1988 where the following decision was taken:

The whole meeting is unanimous in its decision that Swaziland should form its own synod, but still remain part of the General synod of the N.G.K.A. ${ }^{10}$ in South Africa. The secretary will start negotiations with the relevant bodies so that this matter may be concluded as soon as possible. (RVS 1988a:1)

On 24 February 1988 this request was formally communicated to the secretary of the DRCA NTvl in order for it to be placed on the agenda of the synod meeting, which was scheduled for September 1988.

It is clear that the church in Swaziland wished to remain part of the DRCA and that there was no intention nor any desire to break the bond with the 'mother' church in South Africa.

However, the administrator of the DRCA NTvl advised the church in Swaziland to reconsider its decision to remain part of the DRCA and rather to become an independent Reformed church that would maintain its bond with the larger family of DRCs through the Federal Council of DRCes, and the Swazi church was further encouraged to contact the Reformed Church in Botswana, which had already gone through the same process at an earlier stage, for their advice. ${ }^{11}$ A letter was sent to the secretary of the church in Botswana, A.B. Cloete, and in his reply on 25 April 1988 he also advised the church in Swaziland to rather consider becoming an independent Reformed church.

These suggestions were seriously considered by the Church Office Committee (COC) of the presbytery of Swaziland and the following suggestion was formulated to serve before the following meeting of the presbytery:

We report to the presbytery that it will be to our advantage to form an independent synod. We propose that we ask the synod of Northern Transvaal for permission to do this. If the synod has

10.NGKA is the Afrikaans version of DRCA.

11.Letter from H J Möller dated 21 March 1988. to refer the request to the general synod for permission, then we ask for permission to form a regional synod under the N.G.K.A. (COC 1988:1)

The following served as motivation for this suggestion:

1. Language problem at synods. Afrikaans is the language medium and the people from Swaziland do not understand what is being said. Discussions cannot be followed and our representatives cannot actively partake in the discussions.

2. Circumstances in South Africa differ vastly from the circumstances in Swaziland. Our representatives do not understand the problems which are discussed at the meetings, while problems, important to the church in Swaziland, are never discussed.

3. Problems to obtain passports hinder the members of the church in Swaziland to attend meetings of the synod, C.J.V., ${ }^{12}$ C.V.V., ${ }^{13}$ choir competitions and other conferences.

4. The high costs of transport to the Republic and general transport problems make it very difficult to travel to South Africa. (COC 1988:1)

This suggestion from the COC was however rejected by the presbytery, which then made the following decision:

The suggestion from the Church Office Committee to apply from the synod of Northern Transvaal to form an independent synod was not approved, but it was decided to keep to the original decision to apply to become a synod under the Nederduitse Gereformeerde Kerk in Afrika. (RVS 1988b:5)

At the synod meeting of the DRCA NTvl in September 1988 the request from the church in Swaziland was approved and the date of the official forming of the new synod was set for 01 April 1989 (BR 1988:20). However, during the same meeting, the law commission of the DRCA NTvl also recommended that the regional synod of Swaziland should rather consider becoming an independent Reformed church. The presbytery of Swaziland, which had met immediately after the request to become a synod was approved, accepted this recommendation but only on condition that the new synod of Swaziland would also approve it (RVS 1988c:1).

\section{The official forming of the new synod}

The weekend of 31 March to 02 April 1989 marked the end of the presbytery of Swaziland and the forming of the regional synod of Swaziland. A number of visitors from South Africa attended the festivities, which were held in Manzini, including three of the four members of the modarature of the DRCA NTvl, that is, Rev. M.M. Maphoto (moderator), Dr T.A. Mofokeng (assessor) and Rev. L.S. Mataboge (actuary). Dr J.J. Kritzinger (secretary) was unable to attend. Soon after the forming of the new synod of Swaziland had been approved by the DRCA NTvl, work started on the formulation of the

12.Christian Youth Society.

13.Christian Women's Society. 
regulations of the synod. ${ }^{14}$ At this last meeting of the presbytery of Swaziland on 31 March 1989, the regulations additional to the church order were approved after a number of corrections had been made (RVS 1989:1-2). ${ }^{15}$

The presbytery meeting was continued on Saturday, 01 April 1989. During the afternoon session, the delegates from the DRCA NTvl joined the meeting. Although the church order and additional regulations had already been approved the previous day, they requested that further changes be made to the regulations. One of these, Regulation 8 , which referred to the calling of ministers from other churches belonging to the family of DRCs outside of Swaziland read: 'Those who have accepted their calling, become members of the N.G. Kerk in Afrika after their membership certificates have been received'. It was required that this sentence be changed to the following: 'Those who have accepted their calling, become members of the N.G. Kerk in Afrika (Swaziland Reformed Church) after their membership certificates have been received' (RVS 1989:5). Thus, at the request of the modarature of the DRCA NTvl, the indigenous name of the church in Swaziland was included in the new church order.

The meeting was concluded with scripture reading and a short message by Rev. W.C. Bester, with special emphasis on Exodus 33:15: 'If your Presence does not go with us, do not send us up from here'. After reading and approving the minutes of the meeting, the presbytery of Swaziland was officially ended.

Rev. Maphoto, moderator of the synod of the DRCA NTvl, took the chair to guide the meeting as it constituted as a synod. After the Swaziland delegates had handed in their credentials, it was declared that the new synod was officially constituted. The following members were chosen on the modarature:

- Moderator: H.E. Basson

- Secretary: A. van Wyngaard

- Additional member: P.M. Gama

The next morning the meeting continued. The DRCA NTvl delegation expressed their concern about the manner in which the modarature of the SRC was chosen, which allowed two (white) South Africans and only one (black) Swazi to be chosen. After a lengthy discussion, another change to the regulations was demanded. Regulation 38.1 now read:

Directly after the meeting has been opened by the previous moderator, the new moderamen ${ }^{16}$ will be chosen which will

14.The DRCA has a church order that consists of a number of articles. Each regional synod forming part of the DRCA has a separate set of regulations, which are formulated in accordance with the church order but which make allowance for specific circumstances within the regional synod.

15.Of special note is the heading of the church order, which reads: 'Nederduitse Gereformeerde Kerk in Afrika - Church order and additional regulations'. And then the Introduction, which starts with the words: 'The official name of the the Introduction, which starts with the words. The reficial name of the Reforduitse Gereformeerde Kerk in Afrika in Swaziland will be: The Swaziland
Reformed.

16. The leadership of the DRCs is known as the 'moderature'. The term 'moderamen' is more commonly used by the Swaziland Reformed Church. consist of the moderator, the secretary of the synod, the actuarius and the assessor. ${ }^{17}$ (SRC Synod 1989:1)

After a church service, at which time the Lord's Supper was celebrated, the synod meeting continued. In accordance with the change in the church order that had been requested during the morning's session, the modarature was reconstituted:

- Moderator: H.E. Basson

- Secretary and Administrator: A. van Wyngaard

- Actuary: P.M. Gama

- Assessor: J. Sihlongonyane. (SRC Synod 1989:2)

For the following two years the synod of Swaziland functioned basically in the same way that the former presbytery had functioned, but without having to comply with the expectations of the DRCA NTvl in terms of reporting and the attending of committee meetings in South Africa.

\section{Preparing for the unification of the Dutch Reformed Church in Africa and the Dutch Reformed Mission Church}

During this time the DRCA and the Dutch Reformed Mission Church (DRMC), both situated in South Africa, were engaged in a dialogue to enable the two churches to unite. This was in accordance with a decision taken by the DRCA at their previous synod meeting in Umtata (NGKA 1987:384, 417). Because the synod of Swaziland was part of the DRCA, it meant that it would also become part of the planned new united church, should this process be successful.

Although the regional synod of Swaziland had not yet been formed at that stage, a letter of invitation was received from Dr M.S. Pitikoe, Secretary of the DRCA, to attend a combined meeting of the modarature of the DRCA together with the modaratures of all the regional synods of the DRCA. ${ }^{18}$ The meeting took place in Bloemfontein on 24 February 1989 and focussed mainly on the church finances, although the unity process was also on the agenda. The Swaziland church was represented at this discussion by Rev. A. van Wyngaard.

On 14 August 1989 a concept church order for the planned united church was received from Dr Pitikoe. On 21 May 1990 an official invitation was received from the DRCA to attend an extraordinary meeting of the general synod of the DRCA from 01 to 07 October 1990 to discuss the proposed unification of the DRCA and the DRMC. Because the general synod of the DRCA had not yet constituted after the regional synod of Swaziland had been formed in 1989, a letter was sent by the secretary of the DRCA NTvl ${ }^{19}$ in which the church in

17.The moderator is the chairperson of the synod, the assessor is the vice-chairperson and the actuary specialises in the church order.

18.Letter dated 18 January 1989.

19.Letter dated 12 July 1990. 
Swaziland was instructed to attend this meeting, not as regional synod of the DRCA, but to send the same delegates who had attended the previous general synod of the DRCA, when the Swaziland presbytery had still existed. H.E. Basson and P.M. Gama were therefore instructed to attend this special synod meeting in Cape Town.

Shortly before this meeting a letter was received from the actuary of the DRCA, Dr N.J. Smith, in which three matters were discussed: ${ }^{20}$

1. The permanent law commission of the DRCA had approved the forming of the new synod in Swaziland and acknowledged that it had been done correctly according to Article 31 of the church law.

2. On the letterhead used when informing the DRCA officially about the forming of the new synod, ${ }^{21}$ the name 'Swaziland Reformed Church' had been used and the name of the DRCA, to which the new synod belonged, should be indicated in the name of the new synod.

3. It was reiterated that the same two representatives who had attended the DRCA synod in Umtata in 1987 should attend the special synod meeting scheduled for October 1990.

On 18 September 1990, the secretary of the SRC explained the background to the decision to change the name of the Swaziland church to 'Swaziland Reformed Church':22

1. In Swaziland the DRCA was typically referred to as the 'apartheid church', which led to a reluctance from Swazi people to join the church.

2. The Swaziland government refused to register a second 'Dutch' church for Swazi people, as the exclusive white and Afrikaans-speaking 'Dutch Reformed Church' was already registered as an official church.

3. To comply with the request from the permanent law commission of the DRCA, a sentence was included in the constitution of the SRC that stated: "The official name of the Nederduitse Gereformeerde Kerk in Afrika in Swaziland will be: THE SWAZILAND REFORMED CHURCH'.

4. It was emphasised that the SRC had no desire to break its bonds with the DRCA but merely chose to use a more acceptable name for the synod within Swaziland in an attempt to make the church more accessible for the Swazi people.

No response was received regarding this letter to the DRCA.

Despite much controversy during the special synod meeting of the DRCA, the eventual decision was that the unification process would proceed at a meeting of the General Synod of the DRCA to be held in Pretoria during July 1991.

20.Letter dated 11 September 1990.

21.Letter dated 18 December 1989.

22.Letter from the secretary of the SRC to the actuary of the DRCA dated 18 September 1990
In November 1990 another letter ${ }^{23}$ was sent by the secretary of the SRC to the actuary of the DRCA, requesting that English translations of the Belhar Confession, which was going to play a crucial part in the uniting process of the DRCA and the DRMC, be supplied to the SRC. It was felt that the church in Swaziland had to be knowledgeable about the contents of the confession before attending the synod meeting in Pretoria. In an undated ${ }^{24}$ response from the actuary of the DRCA, Dr Nico Smith, the SRC was thanked for its willingness to study the document and to accept the confession beforehand, but as the actuary himself had no English translations available of the document the SRC was advised to write to the secretary of the DRMC, Dr Andries Botha, to ask for English copies of the Belhar Confession.

On 29 January 1991 this request was directed to the secretary of the DRMC, but no response was received from him. On 04 May 1991 a second letter was written to the secretary of the DRMC, again without receiving any response, which eventually meant that the Swaziland church had to attend the unification synod without having had the opportunity to study the Belhar Confession, the most crucial document in the unification process.

In May 1991 the secretary of the SRC received a telephone call from the secretary of the DRCA, Dr Pitikoe. He enquired about the lack of presbyteries in the synod of Swaziland. In a written response, ${ }^{25}$ the secretary of the SRC referred to the additional regulations of the church order of the SRC, specifically Regulation 36 , in which it is stated that ' $[a] 11$ work of the presbytery is taken over by the synod and the work of the commission of the presbytery is taken over by the moderamen' (CO 1989:14). ${ }^{26}$

Shortly before the unification synod meeting started on 09 July 1991, the secretary of the DRCA called the secretary of the SRC again to inform him that the synod in Swaziland would not be allowed to constitute as part of the general synod, based on the argument that the synod of Swaziland had changed its name and was therefore no longer part of the DRCA. Mention was also made of the small size of the synod, which at the time consisted only of three congregations. The SRC was also accused that its delegation appointed to attend the general synod was unconstitutional, as it had not been chosen in accordance with Article 32.1.2, which states that the general synod consists of 'one minister and one elder or evangelist from every presbytery within the area of the composing regional synods'. As the SRC had no presbyteries, it was impossible to comply with this regulation. The SRC was therefore advised to recall its application to be a regional synod and to become a 23.Letter dated 20 November 1990.

24.This letter was written around mid-January 1991.

25.Letter dated 27 May 1991

26.The DRCA later denied receiving this letter, although it was sent both by regular post and also sent as a fax, with a confirmation that the fax had been delivered correctly. 
presbytery under the synod of Northern Transvaal again, if it wished to remain part of the DRCA:

1. The SRC immediately drafted a written response ${ }^{27}$ to this decision, reacting to the objections received from the DRCA. In this letter the following points were made: It was acknowledged by the DRCA that the forming of the synod in Swaziland had been done correctly and in accordance with the prescribed regulations in the church order.

2. As early as 18 September 1990 the reason for the indigenous name of the synod of Swaziland had been explained in a letter directed to the actuary of the DRCA.

3. When the name of the church in Swaziland had been chosen in 1984, because of the stigma which the DRCA had in Swaziland where it was known as the 'apartheid church', it was clearly stated that there was no intention for the SRC to break its bond with the DRCA.

4. The church order of the SRC clearly stated in its heading that the name of the DRCA in Swaziland would be the SRC.

5. There existed no uncertainty that the SRC was part of the DRCA.

6. At a meeting of the SRC synod not long before, it was reiterated that the SRC had no desire whatsoever to exist apart from the DRCA.

7. It made no sense, after everything that had happened and had been approved by the different relevant bodies, for the SRC to consider becoming part of another regional synod once again. As the DRCA had already acknowledged that the process of the forming of the synod in Swaziland had happened correctly and in accordance with the church order, they had to welcome the new synod in their midst.

8. The argument that the synod only consisted of three congregations was irrelevant, as the church order did not stipulate a minimum number of congregations before a synod could be formed and the relatively small size of the church in Swaziland was well known. In fact, the actuary of the general synod of the DRCA, Dr N.J. Smith, had been present when this matter was discussed at the synod of Northern Transvaal in 1988 and was fully aware of the circumstances that led to the forming of the new synod in Swaziland.

9. It was indicated that the delegation to the general synod had been chosen in accordance with Article 32.1.1 of the church order, which states that every regional synod has the right to delegate four members to the general synod and that, in the case of the SRC, only these four members ${ }^{28}$ were delegated to represent the SRC.

10. If, as it was put, the main problem was that the name of the SRC appeared on the letterheads, the SRC would be willing to use the name of the DRCA on its official letterheads.

27. Letter to the secretary of the DRCA dated 29 June 1991.

28.The four primaria members were J.M. Louw, P.M. Gama, J. Sihlongonyane and A. Makhunga while H.E. Basson, W.C. Bester, A. van Wyngaard and M. Ndzimandze were chosen as secundi members (NGKA 1991:351-352; SRC synod 1991a:1)

\section{Dutch Reformed Church in Africa General Synod: 09-16 July 1991}

In anticipation of the general synod meeting, the General Synodical Committee of the DRCA had requested the DRCA NTvl to give their opinion on the legal status of the synod of Swaziland. A letter from the secretary of the DRCA NTvl to the secretary of the DRCA states that the synod that had met on 22 April 1991 discussed the forming of the synod of Swaziland and was of the opinion that, according to the church order, no error was made in the process of forming the synod (NGKA 1991:305). The matter was therefore referred back to the modarature of the DRCA.

After taking note of the findings of the DRCA NTvl, the modarature decided to refer the matter to the general synod to decide about the future of the church in Swaziland as part of the DRCA. Of special concern for them at this stage was that the work of the presbyteries had been taken over by the synod and that there were only three congregations in this synod (NGKA 1991:303).

Before the general synod started on 09 July 1991, a temporary law commission was appointed to discuss the attendance of the delegates from Swaziland and to advise the synod accordingly. Three problems were mentioned in their report (TLC 1991:1):

1. Change of name from NGKA to SRC.

2. Change of Church Order.

3. Election of delegation to this Synod. (Art. 32.1+2)

The following findings were made:

- Change of name: The Synod of Swaziland has adopted the name 'Swaziland Reformed Church'. The Permanente Regskommissie pointed the implications thereof to the above Regional Synod and advised it to revert to the official name (Agenda p 48 pt 4). They did not comply. This means that their status at this meeting as expressed by the letter of credentials is compromised. In other words it cannot be legally valid to accord the delegation from that Regional Synod a voting right at this Synod.

- The status of the Synod of Swaziland: The Synod of Swaziland has, by changing its name, assumed a different identity and thereby ceased to exised [sic] as a Regional Synod of the NGKA.

- Change of Kerk Orde [sic]: It has not been changed, but in its implementation for purposes of electing a delegation to this Synod it was not strictly applied. (Art. 32.1.2)

The temporary law commission therefore made the following recommendation: 'The Synod accords observer status to the delegation in question' (TLC 1991:1). ${ }^{29}$

29.Ironically the chairperson of this committee was Rev L.S. Mataboge, who had been the actuary of the DRCA NTvl in 1988 when the forming of the Swazi synod had the actuary of the DRCA NTVl in 1988 when the forming of the Swazi synod had been approved, and the actuary of the committee was Dr. T.A. Mofokeng, who had been the assessor of the synod of the DRCA NTVl in 1988. Both had also been resent during the weekend of 01 and 02 April 1988 when the synod of Swaziland had officially been formed and both had also, together with the moderator of the DRCA NTVl, Rev. M.M. Maphoto, approved the additional regulations of the synod of Swaziland on 01 April 1988. 
In the official agenda for the meeting of the general synod, it is stated that the synod in Swaziland had changed its name to the 'Swaziland Reformed Church' and, despite being informed that this was not allowed, the regional synod of Swaziland had not replied to this objection (NGKA 1991:48).

However, while the DRCA maintained that the SRC had not responded to their correspondence regarding the name change, three letters had in fact been written by the SRC to the DRCA in response to this issue, ${ }^{30}$ of which two had been both posted and faxed to ensure that they reached their destination. It was later denied that any of these letters had been received.

In its discussion of the status of the SRC during the meeting of the general synod, the following decision was made: 'The Synod of Swaziland had, by changing its name, assumed a different identity and thereby ceased to exist as a Regional Synod of the NGKA' (NGKA 1991:396).

The delegation from Swaziland was informed that they were no longer part of the DRCA and that they should return to Swaziland to constitute their own church. Although the modarature of the SRC requested a review of this decision in a private discussion with both the moderator of the DRCA, Rev. S.P.E. Buti and Dr N.J. Smith (actuary), they refused to further discuss the issue and the Swaziland delegation left the meeting.

On Monday 15 July 1991 the Afrikaans newspaper, Beeld, reported on this decision by the DRCA and mentioned that there was talk behind the scenes that the DRCA was afraid that the Swaziland synod with four white missionaries working there would put a spoke in the wheel of the unification process and that the only way in which to prevent this was to break the bond with the Swaziland church (Beeld 1991:4).

\section{The autonomous Swaziland Reformed Church}

On its return to Swaziland, the synod had to make decisions about its future. Rev. Van Wyngaard was asked to prepare a working document in which the different possibilities for the future would be discussed. There were five possible options:

1. change the name of the SRC to the DRCA

2. become an independent church

3. become an independent Reformed church

4. combine with one of the other existing churches in Swaziland or

5. become part of the white, Afrikaans-speaking, DRC. ${ }^{31}$

After the synod had had a lengthy discussion about the feasibility of each of these options, the following decision was made:

30. Letter to the DRCA actuary, 18 September 1990; letter to the DRCA secretary, 27 May 1991; letter to the DRCA secretary, 29 June 1991.

31.Report presented to the synod of Swaziland, 15 October 1991.
1. The synod decides that it is presently an independent Reformed church in the Federal Council of DRCs.

2. The synod decides in principle that it is in favour of uniting with the DRC.

3. The synod will start discussions with the DRC on the local level as well as on a more official level to implement this unity. (SRC Synod 1991b:3)

A letter was written to Dr F. Gaum, secretary of the DRC, in which this decision was communicated. ${ }^{32}$ On 16 January 1992 he suggested that a meeting be held between the Eastern Transvaal modarature of the DRC, the modarature of the DRC as well as the modarature of the SRC. The proposed date for this meeting was 28 February 1992.

At the next synod meeting of the SRC, held on 25-27 August 1992, a report on this meeting with the DRC was presented to the synod in which it was clear that the DRC was open for the SRC to join them, stating that 'any request which we might have to become part of the Dutch Reformed Church will be acceptable to them' (Future of SRC 1992:1). The DRC furthermore suggested that either of two options could work, one being that the SRC join the DRC as a regional synod and the other that the SRC become a presbytery, which would then function under the regional synod of the DRC of Eastern Transvaal.

This offer was discussed at the synod meeting, and although there was a strong desire that the SRC should unite with the DRC on synodical level, it was clear that the local DRC congregation ${ }^{33}$ would not be open to unite with the congregations of the SRC nor to become part of a presbytery or synod in which the Swazi members were the majority. The synod therefore made the following decision:

1. The synod repeats its decision that the SRC is in favour of uniting with the DRC.

2. Because of practical problems in Swaziland, the time is not yet ripe for such unification to take place.

3. The secretary of the synod will write a letter to the secretary of the General Synodical Committee of the DRC to thank the church for its willingness to accept the SRC as part of the DRC and to inform him of the above decisions. (SRC Synod 1992:7)

At the same meeting the forming of a fourth congregation for the Lubombo district in Swaziland was approved.

The modarature of this first synod of the autonomous SRC was Rev. H.E. Basson (moderator), Rev. M.T. Shongwe (vice-chairperson), Rev. J.M. Louw (actuary) and Dr A. van Wyngaard (secretary).

\section{Conclusion}

There is no official date on which the SRC became an autonomous Reformed church. In principle it happened 32.Letter dated 18 October 1991.

33.The Goedgegun congregation of the DRC in Swaziland is still exclusively white and Afrikaans-speaking. 
during the meeting of the general synod of the DRCA in July 1991, when the bond between the DRCA and the SRC was officially broken. In practice it happened on 25 August 1992 when the new synod of the SRC was constituted and the new moderamen was chosen.

As can be concluded from correspondence as well as official minutes of meetings, the adoption of the name 'Swaziland Reformed Church' was never intended to indicate a break in the bond with the DRCA. While the DRCA maintained that the SRC never responded to their letters regarding the name of the church in Swaziland, the opposite was true: despite letters of explanation having been posted and faxed to the office of the DRCA, there was no acknowledgement from this office that the correspondence had been received. Even when the SRC was willing to comply with the wish of the DRCA to change the official letterheads back to the name of the DRCA, there was no response from the DRCA. At the meeting of the DRCA in Pretoria in July 1991, when the SRC tried for a last time to prevent the DRCA from forcing the SRC to become an independent Reformed church, a conversation about the matter was refused.

From the start, the legal status of the synod of Swaziland was acknowledged by various bodies, including the permanent law commission of the DRCA as well as the synod of Northern Transvaal. The church order of the synod of Swaziland was approved by the modarature of the DRCA NTvl, who had been present at the occasion when the new synod was constituted on 01 April 1989.

The future will indicate whether this decision by the DRCA to break the bond with the SRC at the very meeting where the unification between the DRCA and the DRMC took place to form the new Uniting Reformed Church of Southern Africa (URCSA) was for the good or for the bad of the church in Swaziland.

\section{Acknowledgements Competing interests}

The author declares that he has no financial or personal relationships which may have inappropriately influenced him in writing this article.

\section{References}

Beeld, 1991, Aansluiting by NG Kerk 'n opsie vir Swazi-sinode, Beeld, Pretoria, South Africa.

BR, 1983, Ring van Piet Retief: Besluiteregister, Ararat, Swaziland.

BR, 1984, NGKA Noord-Transvaal: Besluiteregister, Mamelodi, South Africa.

BR, 1988, NGKA Noord-Transvaal: Besluiteregister, Mamelodi, South Africa.

CO, 1989, Church order of the Swaziland Reformed Church 1 April 1989, Manzini, Swaziland.

COC, 1988, Minutes of a meeting of the Church Order Committee 9 August 1988, Nhlangano, Swaziland.

DRC, 2011, The church order, viewed 16 August 2017 from http://www.ngkerk.org.za/ downloads/CHURCH-ORDER-2011-1.pdf

Future of SRC, 1992, Report on the future relationship of the SRC and DRC, Manzini, Swaziland.

NGKA, 1987, Agenda en Handelinge van die sinode van die NGKA 10 June 1987, Umtata, Transkei.

NGKA, 1991, Agenda en Handelinge van die sinode van die NGKA 9 July 1991, Pretoria, South Africa.

RK, 1984, Notule van die Ringskommissie van Swaziland 8 August 1984, Manzini, Swaziland.

RVPR, 1980, Notule van die Ring van Piet Retief 5 March 1980, Pongola, South Africa. RVS, 1984a, Notule van die Ring van Swaziland 25 Junie 1984, Pretoria, South Africa. RVS, 1984b, Notule van die Ring van Swaziland 23 November 1984, Mbabane, Swaziland.

RVS, 1985a, Notule van die Ring van Swaziland 30 January 1985, Manzini, Swaziland.

RVS, 1985b, Notule van die Ring van Swaziland 21 September 1985, Dwaleni, Swaziland.

RVS, 1987, Notule van die Ring van Swaziland 25 September 1987, Siteki, Swaziland.

RVS, 1988a, Notule van die Ring van Swaziland 19 February 1988, Phemba, Swaziland.

RVS, 1988b, Minutes of a meeting of the presbytery of Swaziland 26 August 1988, Hlushwana, Swaziland.

RVS, 1988c, Minutes of a meeting of the presbytery of Swaziland 26 September 1988 Mamelodi, South Africa.

RVS, 1989, Minutes of a meeting of the presbytery of Swaziland 31 March 1989, Manzini, Swaziland.

SRC Synod, 1989, Minutes of a meeting of the synod of Swaziland 1 April 1989, Manzini, Swaziland.

SRC Synod, 1991a, Minutes of a meeting of the synod of Swaziland 23 May 1991, Manzini, Swaziland.

SRC Synod, 1991b, Minutes of a meeting of the synod of Swaziland 15 October 1991, Manzini, Swaziland.

SRC Synod, 1992, Minutes of a meeting of the synod of Swaziland 25 August 1992, Manzini, Swaziland.

SRC Synod, 2017, Agenda of a meeting of the synod of Swaziland 7 September 2017, Manzini, Swaziland.

SwSK, 1976, Notule van die Swazilandse Sendingkommissie 7 Mei 1976, Phemba, Swaziland.

SwSK, 1984, Notule van die Swazilandse Sendingkommissie 11 November 1984 Mbabane, Swaziland.

TLC, 1991, First report of the temporary law commission to the synod of the DRCA 9 July 1991, Pretoria, South Africa.

Van Wyngaard, A., 2018. 'The Dutch Reformed Church Mission in Swaziland - A dream come true', Hervormde Teologiese Studies 74(1), 1-7. https://doi.org/10.4102/
hts.v74i1.4785 